\title{
Estimating FBO Employment in the United States
}

\author{
John K. Voges, Michael F. Robertson, Matthew J. Romero, and David A. NewMyer \\ Southern Illinois University Carbondale
}

\begin{abstract}
The purpose of this paper is to document the number, distribution, and categories of employees working at fixed base operators (FBOs) in the United States (U.S.). A secondary purpose is to document the types of services offered by FBOs in the U.S. The methodology used in this paper was a combination of literature review and survey research. In the literature review, the U.S. Census Bureau's North American Industry Classification System was consulted along with private sources such as the World Aerospace Database (WAD), the Independent Fixed Base Operators Association, and the National Air Transportation Association. In the survey, a total of 3,211 FBOs were sent a one page survey regarding FBO employment and services, of which only 941 FBOs returned a survey (or 29.3\%). This response rate limits the results of the survey to describe the characteristics of the study group only and not the entire FBO sector of the aviation industry. The respondents reported a total of 15,965 employees. An additional 61,169 employees were found at FBOs listed in the WAD, with 4,454 of those at FBOs covered by the survey, leaving a total of 56,715 additional employees not covered by the survey. Combining the two totals provides a total of 72,680 employees at FBOs in the U.S.
\end{abstract}

\section{INTRODUCTION}

The services provided by fixed base operators (FBOs) have been a staple of general aviation since the earliest days of flight. The FBOs in the United States (U.S.) provide a variety of services such as line service, aircraft maintenance, new and used aircraft sales, parts sales, flight training, and aircraft charter services (Wells \& Chadbourne, 2003). These organizations provide a conduit through which the general public may gain access to the aviation community. The nation's FBOs provide a valuable contribution to the aviation industry which deserves further investigation. Identifying the contribution of domestic FBOs to the national aviation industry will enable a better understanding of the composition of general aviation and its effect on the aviation industry.

This paper provides a method to identify the contribution made to the aviation industry by FBOs through two indicators. First, this paper documents the number, distribution, and categories of employment at FBOs in the U.S. The second method used to document contribution is to identify the number, types, and breadth of services offered by domestic FBOs. This paper is significant because it supplies the aviation community with a more detailed description of the characteristics of the FBO sector than currently exists.

\section{LITERATURE REVIEW}

The literature reviewed for this study concentrated on sources that identify companies providing services similar to FBO related activities. Three sources were utilized to create a list of FBOs in the U.S. It was also necessary to examine the literature for sources indicating the number of employees engaged in FBO related work. Federal industry classifications were used to identify definitions of aviation employment categories.

Before the authors could search for documentation regarding the type of work performed by FBOs and the number of employees employed in the FBO sector, it was important to identify a comprehensive definition for an FBO. Wells and Chadbourne (2003) provide the most thorough definition of FBO related work:

The principal business of fixed base operators is line service, which includes the retail sales of fuel and oil, minor repairs, emergency service and other flight continuation services for general aviation aircraft. They also maintain storage facilities for private airplanes, provide continuing maintenance and overhaul services, and usually have small and medium-sized airplanes 
available for charter. Some of the larger FBOs are active in selling new and used airplanes, and some operate flying schools. A few of the larger operators are equipped to offer complete flight service arrangements for business firms, including supplying both aircraft and crews (p. 64).

Conceivably a better descriptor more reflective of the array of services offered at these facilities would be "General Aviation Service Center" or "Aviation Service Business," but the commonly accepted definition of an FBO provided by Wells and Chadbourne gives the authors a foundation from which to identify FBO-type companies (Rodwell, 2003, p.2).

Four primary sources were used to gain an understanding of the breadth of the FBO industry in the U.S.: (1) U.S. Census Bureau's North American Industry Classification System (NAICS), (2) The World Aerospace Database (WAD), (3) the Independent Fixed Base Operator Association (IFBOA) member list (www.ifboa.aero), and (4) an FBO search engine maintained by AC-U-KWIK (www.acukwik.com). The AC-U-KWIK web site was eventually used to generate the mailing list for the survey associated with this study.

\section{U.S. Census Bureau}

The Census Bureau provides a classification system by which the occupations within our economy are divided into different sectors and subsectors. The system is known as the NAICS, and it "is the standard used by Federal statistical agencies in classifying business establishments" (NAICS, 2008, Introduction Section, \ 1). For the purposes of this study, the NAICS was used to identify official classifications of aviation employment as defined by the federal government.

According to the Report on the American Workforce (U.S. Department of Labor [DOL], 2001), the "NAICS divides the economy into 20 sectors....Industries within these sectors are grouped according to the production criterion" (DOL, p. 99). Each grouped sector is divided into different categories and subcategories. Each level of the NAICS provides industry employment categorization with increasing specificity. Aviation related employment categories are found in two major sectors within the NAICS; sector 48 (Transportation and Warehousing) and sector 61 (Educational Services). Most of the aviation industry employment categories are encompassed within the transportation and warehousing sector of the NAICS.

The industry is divided into three broad categories: (1) scheduled air transportation, (2) non-scheduled air transportation, and (3) support activities for air transportation. Aviation flight training is included in the educational services sector: 61-educational services.

The activities associated with scheduled air transportation are described as those involving "transportation of passengers and/or cargo over regular routes and on regular schedules" (NAICS, 2007, p. 348). This category does not represent the activities of the FBO industry because an FBO's activities do not involve operating within regular schedules and do not necessarily involve regular routes.

The nonscheduled air transportation sector is more closely related to the activities of FBOs. This sub-sector of air transportation is defined as those organizations that are "primarily engaged in (1) providing air transportation of passengers and/or cargo with no regular routes and regular schedules or (2) providing specialty flying services with no regular routes and regular schedules using general purpose aircraft" (NAICS, 2007, p. 349). This definition provides two characteristics that are similar to FBO related activities. Irregular schedules and routes are related to charter operations which is a component of the FBO industry. The inclusion of "general purpose aircraft" into the definition is also characteristic of FBO activities such as charter operations and flight instruction. But these activities do not fully encompass the range of FBO related activities.

The third NAICS employment category related to aviation is called support activities for air transportation. This sector is divided into more detailed sub-sectors: (1) airport operations and (2) other support activities for air transportation. The airport operations category is defined by the NAICS as activities such as “(1) operating international, national, or civil airports or public flying fields or (2) supporting 
airport operations..., such as rental of hangar space, air traffic control services, baggage handling services, and cargo handling services" (NAICS, 2007, p. 365). The hangar space rental is the only portion of this definition that relates to the activities of FBOs. Other Support Activities for Air Transportation is defined as a broad generalized category that could be related to many of the activities typically performed by an FBO.

Flight training is the last category of employment within the NAICS that applies directly to the FBO industry. This employment sector is defined as "establishments primarily engaged in offering aviation and flight training" (NAICS, 2007, p. 481).

\section{World Aerospace Database}

The World Aerospace Database (WAD) was examined to identify a current listing of FBOs and their employees. The WAD is a key provider of data for service related organizations within the aerospace industry. These organizations include airlines, manufacturers, MRO repair stations, airports, distributors/suppliers, product/service vendors and aviation/aerospace professionals for commercial, military \& business aviation. The WAD was examined as a preliminary source for survey recipients, but AC-U-KWIK later proved to be a more comprehensive resource for FBOs in the U.S. The directory was used to identify the published number of domestic FBOs and their employee data, though not all organizations disclose this information in the WAD.

\section{Independent Fixed Based Operator Association}

The IFBOA is an organization whose mission is to "increase the marketability and profitability of its members through the interchange of knowledge, enhanced purchasing capabilities, shared marketing, and common objectives” (IFBOA, 2008, Mission Statement). The IFBOA provides a list of nearly 100 members on their website, but no employment data was provided through by this organization.

\section{AC-U-KWIK}

The last source of FBO data reviewed was a website known as "AC-U-KWIK: Your Global Resource for Aviation Information” (www.acukwik.com). This resource provided the most comprehensive list of FBOs in the U.S. As described in the following section, this website provides a list of more than 3,000 organizations performing FBOs related services. This was the source used to generate the mailing list for the employment survey.

\section{METHODOLOGY}

This section describes the process used to create a mailing list for the distribution of the survey. The survey provides the number of persons employed by the responding FBOs. This section also provides a description of the method used to calculate the number of companies and their employees published in the WAD. The WAD list of FBO employees was used to identify a baseline of published FBO employee numbers.

\section{Survey Mailing List}

The researchers attempted this survey previously, but the response rate was less than $17 \%$ which warranted another survey using a different resource to identify a survey population. In order to increase the response rate for the second survey attempt, the researchers identified three sources for a recipient list. The three sources were AC-UKWIK, the WAD, and the IFBOA.

The number of organizations listed by ACU-KWIK was more than the combined total of the number of FBOs indicated in the WAD and the number of members of the IFBOA. This provided justification to use the FBOs listed by AC-U-KWIK to create the survey population. A copy of this survey instrument used for this study and the accompanying letter of introduction can be found in Appendix A. What follows is a description of the process used to generate the survey mailing list from AC-UKWIK.

An initial list of FBOs in the U.S. was generated from AC-U-KWIK which can be accessed at acukwik.com. The main page of this web site has several tabs indicating different areas of the website. The tab called "FBOs" provides access to a list of states in the U.S. Each state has a link connecting it to a list of all 
FBOs in that state that subscribe to the AC-UKWIK service.

Next, a list of domestic FBOs was created using the information from the link to each state. The list contains the name of the FBO, the fourcharacter International Civil Aviation Organization (ICAO) airport identifier, mailing address, and phone number. Most of the FBOs in AC-U-KWIK included a mailing address, but some only included a phone number. For those not containing an address within the link, further inquiry was required. Three techniques were used to identify the mailing addresses for these companies. First, the phone number provided in the link to the FBOs information was used to locate these addresses. This was done through a reverse phone number lookup process. This service can be done through White Pages.com (www.whitepages.com /reverse_phone).

The second method used to locate missing addresses was to search for the company name and other specific information relating to the company in an internet search engine. The third method used to locate the missing addresses for airports involved accessing data through an airport database managed by GCR \& Associates, Inc. (www.gcr1.com/5010Web/).

An address was found for most FBOs listed in the AC-U-KWIK data base, the list contained 3,242 fixed base operators in the United States. Some mailing addresses for the organizations on the list could not be located. Therefore, 163 organizations were removed from the list. The total number of FBOs acquired from AC-UKWIK was 3,079 organizations. In addition to the list assembled from AC-U-KWIK, another group of FBOs was included in the mailing list. These FBOs were added from a group of survey respondents from the previous survey of FBOs conducted between 2006 and 2007. The list of previous survey respondents contained 521 FBOs. The previous group of survey respondents was cross-referenced with the newly assembled list of 3,079 FBOs, and 133 of these organizations were not included in the new list and were therefore added to the mailing list. The final mailing list contained 3,211 survey recipients.

\section{Calculating the WAD Employment Number}

The WAD is an annual publication published by Aviation Week that contains a directory of aviation services. Section D13 of the WAD contains aviation organizations categorized as "fixed base operators and companies in ground handling and suppliers of aviation gas, jet fuel or oil” (WAD, 2008, p. 934).

This section provided a list of companies that participate in FBO related activities. This list was refined to include only those FBOs in the U.S. The information related to each company in the WAD FBO section was transferred to spreadsheet software. As mentioned previously, not all of the companies listed in the WAD provide the number of employees working for their organization. The number of FBOs and their employees published in the WAD was easily calculated from this list.

\section{RESULTS}

\section{U.S. Census Bureau}

There are four NAICS employment categories that apply to the FBO sector: (1) nonscheduled air transportation, (2) support activities for air transportation, (3) other support activities for air transportation, and (4) flight training. According to the 2002 NAICS report, 7,999 establishments employ 175,560 workers. Table 1 provides a summation of the NAICS employment categories relevant to the FBO sector of the aviation industry.

Table 1: NAICS Air Transportation Classifications Relevant to FBO Survey

\begin{tabular}{|l|l|c|c|}
\hline \multicolumn{1}{|c|}{ NAICS Code } & \multicolumn{1}{|c|}{ NAICS Code Title } & Establishments & Employees \\
\hline 48121 & Nonscheduled Air Transportation & 2,182 & 32,008 \\
488119 & Other Airport Operations & 1,484 & 57,309 \\
48819 & Other Support Activities for Air Transportation & 3,342 & 71,088 \\
611512 & Flight training & 991 & 15,155 \\
\hline \multicolumn{2}{|c|}{ Totals } & 7,999 & 175,560 \\
\hline
\end{tabular}




\section{World Aerospace Database}

The list of FBOs in the United States from the WAD includes 480 companies providing FBO services, ground handling, and fuel services. The number of employees reported in the WAD is 124,696 , but this is a misleading representation of the FBO employment picture. Two companies were removed from the list. They are Conoco Philips Company of Bartlesville, Oklahoma and Marathon Ashland Petroleum, LLC of Findlay, Ohio. Each of these organizations is involved in petroleum refining and distribution.

The two companies mentioned above report a combination of 63,800 employees in their organizations. Conoco Phillips reports 35,800 employees, and Marathon Ashland Petroleum, LLC reports 28,000 employees. Removing these two organizations and their respective employees will provide a clearer vision of the FBO employment industry according to the WAD. The new total of FBO employees is 61,169 being reported by 478 companies.

From this data the WAD revealed overall that as of 2008, there are 61,169 people employed at FBOs throughout the country. It was determined that 71 of the 941 FBOs who responded to our survey were also contained in the WAD results. This equaled a total of 4,454 employees, leaving 56,715 employees for consideration from the WAD data. The WAD employee data, when combined with the results of the survey, indicated a total of 72,680 employees at FBOs throughout the U.S.

\section{Survey Responses}

The survey was distributed to 3,211 organizations performing FBO related services through three mailings. Of those mailed out, $17.7 \%$ (567) were returned successfully with complete information. Just over 3\% (101) of the surveys mailed to the FBOs were classified as "return to sender". Ninety-three of these addresses were corrected for the second mailing. The great majority $(79 \%$ or 2,537$)$ of the surveys sent to the FBOs did not respond to the first mailing of the survey.

The second mailing contained 2,630 surveys. This mailing yielded 234 (8.9\%) positive responses and $63(2.4 \%)$ returned to sender responses. Nearly $89 \%(2,333)$ of the mailed survey recipients did not respond to the second mailing of the survey. Sixty-two of the "return to sender" surveys were corrected for the third mailing. The third mailing was distributed to 2,396 participants. As of December 3, 2008, the final day of survey submission, the third mailing of the survey resulted in 154 positive responses or $6.43 \%$ of surveys sent as part of the third mailing of the survey. Table 2 illustrates the number of FBO companies that responded to the survey.

Table 2: Survey response results of three mailings of the FBO survey.

\begin{tabular}{|l|c|c|}
\hline \multicolumn{3}{|c|}{ Survey Results } \\
\hline Recipients & 3,211 & Rates \\
\hline Responses & 941 & $29.30 \%$ \\
\hline No Response & 2,055 & $63.99 \%$ \\
\hline Return to Sender & 215 & $6.70 \%$ \\
\hline
\end{tabular}

The authors disseminated 3,211 mailings to FBOs across the country in three groups of mailings. Of these, 941 FBOs responded yielding a return rate of $29.3 \%$. A key limitation to this study is the result of the low response rate. The survey responses cannot be generalized to the national FBO population but are intended to describe the characteristics of the survey respondents. For the survey, participants were asked to provide the total number of employees, number of employees in various categories as well as services offered at their respective FBO.

\section{Survey Employment Results}

The following results reflect information within the context of the survey and do not necessarily reflect FBO employment nationwide. Employees at the 941 FBOs which respond to the survey totaled 15,965. A further breakdown of the position(s) filled by those employees into specific employment categories and the number employed were also provided. These categories included: management, flight instruction/pilot, A \& P mechanics, avionics technician, line service, customer service and other personnel. These employee totals are shown in figure 1 .

\section{Reported FBO Employment by State}

FBOs from each state responded to the survey and reported the number of employees in the specific categories. 


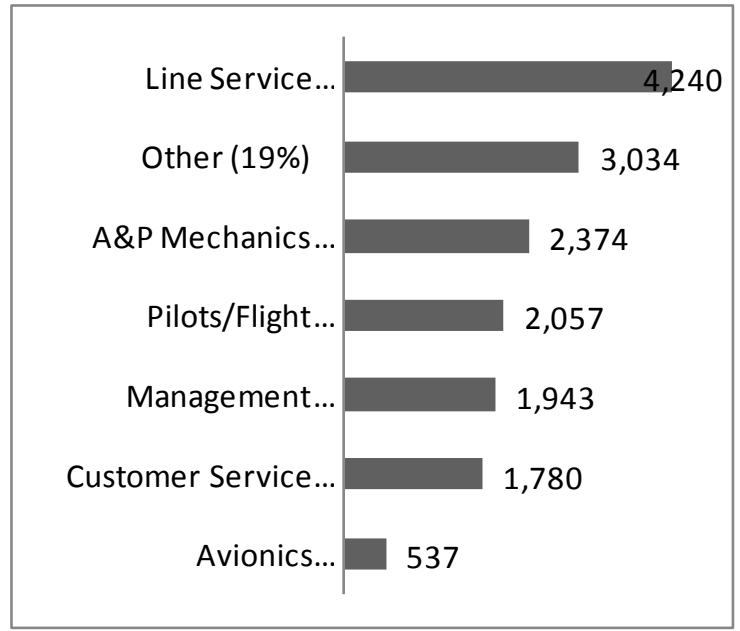

Figure 1: Top reported FBO employment categories.

The top 20 states in terms of total employees in each category are shown in Table 3 . These states and FBOs were selected due to the volume of the statistics collected. The top twenty states and FBOs encompass a large representation of the survey results. These states employ 12,218 of 15,965 (76.5\%) employees reported, while the top 20 FBOs account for $33.6 \%$ of the total number of employees reported by respondents. The top 20 states also accounted for $70 \%$ of management employees, $80 \%$ of flight instruction employees, $81 \%$ of mechanics, $93 \%$ of avionics employees, $69 \%$ of line service employees and $74 \%$ of customer service employees.

The states, in terms of total FBO employment, are shown in Table 4 . Note that Illinois and Michigan, with reported totals of 2,488 and 1,326 employees respectively, are far and away the largest employers of FBO employees. Illinois and Michigan also had the highest number of reporting FBOs in the top 20, with three each (Table 4). Following Illinois and Michigan were Florida with 925 employees, Oregon with 706 employees and Indiana with 621 employees. Of these top five states, in terms of employment, only Illinois was in the top five for the number of FBOs reporting from each state. Illinois had 48 FBOs reporting, followed by Ohio with 46, Texas with 44, Minnesota with 41 and Missouri with 36.

\section{Employment at the Top Twenty Participating FBO's}

The 20 largest FBOs that responded to the surveys reported a total of 5,370 employees. The top 20 FBOs in terms of total employment are shown in Table 5. Note that the top 20 FBOs account for $33.6 \%$ of the total number of employees reported by respondents. As noted in the figure, there are six FBOs that currently employ more than 200 employees: Midcoast Aviation (Cahokia, IL), Duncan Aviation (Battle Creek, MI), Stevens Aviation INC. (Conestee, SC), Million Air (Salt Lake City, UT), Standard Aero (Springfield, IL) and Pentastar Aviation (Walerford, MI). The Midcoast Aviation total of 1,400 employees is the largest FBO employer by far. The remaining sixteen FBO's in the top 20 each had 100 or more employees.

The preceding table represents the top twenty FBOs according to their total employment and total employment by category reported. The top 20 FBOs represent operators where total employment ranged from 1,400 employees to 100 employees. These 20 FBOs reported 5,201 employees out of the 15,965 total and account for nearly one-third, $32.6 \%$ of the total employment of all 941 respondents.

Figure 1 shows the number of employees per category that these 20 employers reported.

\section{FBO Services Offered Nationwide}

Given the wide array of functions that FBOs provide, respondents were asked to report the services offered at their particular FBO. These services included: fuel, charter, flight instruction, aircraft rental, aircraft sales, aerial surveying, pilot supplies, glider towing, airframe/powerplant repairs, avionics, aircraft storage, parachute jumping and crop dusting. The data revealed that nationally, many of the traditional services such as fueling, maintenance and flight instruction are more frequently reported than those considered to be more "specialized" and are available far less often. Of the 941 FBOs responding to the survey, the greatest single activity nationwide was the provision of fuel service at $95 \%$. The second most substantial activity was aircraft storage at $69 \%$. 
Table 3: Employment categories by state

\begin{tabular}{|l|l|c|c|c|c|c|c|c|c|}
\hline \multicolumn{1}{|c|}{ Company } & \multicolumn{1}{|c|}{ City } & State & Total & Mgmt. & $\begin{array}{c}\text { Flight } \\
\text { Instructor }\end{array}$ & Mechanics & Avionics & $\begin{array}{c}\text { Line } \\
\text { Service }\end{array}$ & $\begin{array}{c}\text { Customer } \\
\text { Service }\end{array}$ \\
\hline Midcoast Aviation & Cahokia & IL & 1400 & 34 & 0 & 120 & 120 & 25 & 6 \\
\hline Duncan Aviation & Battle Creek & MI & 700 & 22 & 0 & 187 & 64 & 34 & 48 \\
\hline Stevens Aviation, Inc & Conestee & SC & 358 & 25 & 14 & 140 & 38 & 48 & 8 \\
\hline Million Air & Salt Lake City & UT & 320 & 25 & 36 & 30 & 0 & 57 & 6 \\
\hline Standard Aero & Springfield & IL & 250 & 8 & 0 & 75 & 30 & 4 & 50 \\
\hline Pentastar Aviation & Walerford & MI & 210 & 11 & 46 & 35 & 11 & 12 & 6 \\
\hline Hillsboro Aviation, Inc & Hillsboro & OR & 198 & 14 & 100 & 21 & 5 & 13 & 15 \\
\hline Epps Aviation & Atlanta & GA & 196 & 0 & 0 & 0 & 0 & 0 & 0 \\
\hline Western Aircraft, Inc & Boise & ID & 175 & 22 & 8 & 49 & 15 & 25 & 8 \\
\hline Atlantic Aero & Greensboro & NC & 169 & 5 & 0 & 57 & 7 & 14 & 3 \\
\hline Meridian & Teterboro & NJ & 156 & 11 & 58 & 13 & 1 & 46 & 9 \\
\hline Banyon Air Service & Ft. Lauderdale & FL & 156 & 19 & 0 & 27 & 14 & 36 & 9 \\
\hline Landmark Aviation & Sioux Falls & SD & 145 & 9 & 33 & 24 & 10 & 32 & 9 \\
\hline Spokane Airways Inc & Spokane & WA & 130 & 5 & 4 & 3 & 0 & 5 & 4 \\
\hline Northern Air & Grand Rapids & MI & 116 & 6 & 37 & 19 & 0 & 14 & 22 \\
\hline Jet Source, Inc. & Carlsbad & CA & 113 & 8 & 17 & 10 & 6 & 27 & 9 \\
\hline Landmark Aviation & Scottsdale & AZ & 106 & 4 & 11 & 25 & 3 & 45 & 18 \\
\hline The Flightstar Corp & Savoy & IL & 103 & 19 & 20 & 25 & 1 & 11 & 13 \\
\hline DB Aviation INC & Waukegan & IL & 100 & 20 & 30 & 15 & 0 & 20 & 5 \\
\hline Eagle Creek & Indianapolis & IN & 100 & 8 & 13 & 42 & 8 & 7 & 12 \\
\hline
\end{tabular}

The frequency of the other services at the FBOs were reported as follows: 55\% provide pilot supplies, $46 \%$ perform A \& P repairs, $45 \%$ offer flight instruction, $39 \%$ provide aircraft rental, $27 \%$ provide charter, $25 \%$ report aircraft sales, $12 \%$ service avionics, $10 \%$ have freight, $9 \%$ conduct aerial survey, $8 \%$ provide crop dusting, $3 \%$ offer parachute jumping and $2 \%$ have glider towing.

\section{FBO Services Offered by State}

FBOs from each state responded to the survey and reported the types of services offered at their respective FBO. Many states ranked in the top five for different service categories. Ohio was in the top five for all services except glider towing, crop dusting and aerial survey. Note that the state of Ohio led in 8 of the 13 services offered. Illinois was in the top five for every service except for glider towing. Other notable states that ranked in the top five of different types of service categories included: Iowa (8), Minnesota (7), Wisconsin (5) and Tennessee (4). There were three other states that ranked in the top 5 in three service categories, which included Texas, Florida and Indiana.

\section{Employment categories at the Top Twenty Reporting FBOs}

The frequency of the services offered at these facilities is shown in Figure 2 . Interestingly, these top twenty FBOs reveal similarity with the national trend that the chief activity is aircraft fueling at $100 \%$. However, unlike the reported tendency, aircraft maintenance was reported at $95 \%$. Charter services were also much higher at $85 \%$, with avionics repair and aircraft storage higher and served equally at $80 \%$. Aircraft sales were more prevalent offered at $65 \%$ of these FBOs. Pilot supplies were offered at $40 \%$ and freight services were conducted by only $20 \%$ of the respondents. Surprisingly, just $10 \%$ of these

FBOs provided aircraft rental as well as instruction. Aerial Survey services were provided at only one of the top twenty for 5\% and none of the top twenty respondents offered crop dusting, parachute jumping, or glider towing. 
Table 4: Reporting employees by state

\begin{tabular}{|c|c|c|c|}
\hline \multicolumn{5}{|c|}{ Total Employees by State } \\
\hline State & Total & State & Total \\
\hline IL & 2488 & SD & 208 \\
\hline MI & 1326 & AZ & 206 \\
\hline FL & 925 & VA & 204 \\
\hline OR & 706 & KY & 188 \\
\hline IN & 621 & NM & 166 \\
\hline CA & 554 & NE & 162 \\
\hline OH & 517 & MT & 153 \\
\hline UT & 494 & MA & 150 \\
\hline MN & 472 & WY & 139 \\
\hline NC & 449 & NV & 117 \\
\hline SC & 431 & OK & 106 \\
\hline WI & 421 & AL & 88 \\
\hline TX & 402 & LA & 83 \\
\hline GA & 389 & AR & 80 \\
\hline NY & 386 & CT & 78 \\
\hline WA & 367 & ND & 76 \\
\hline ID & 360 & MS & 75 \\
\hline NJ & 339 & WV & 72 \\
\hline CO & 305 & ME & 67 \\
\hline MO & 266 & NH & 54 \\
\hline IA & 265 & HI & 34 \\
\hline PA & 260 & MD & 33 \\
\hline TN & 254 & VT & 11 \\
\hline KS & 222 & DE & 11 \\
\hline AK & 221 & & \\
\hline & & & \\
\hline & & & 17 \\
\hline
\end{tabular}

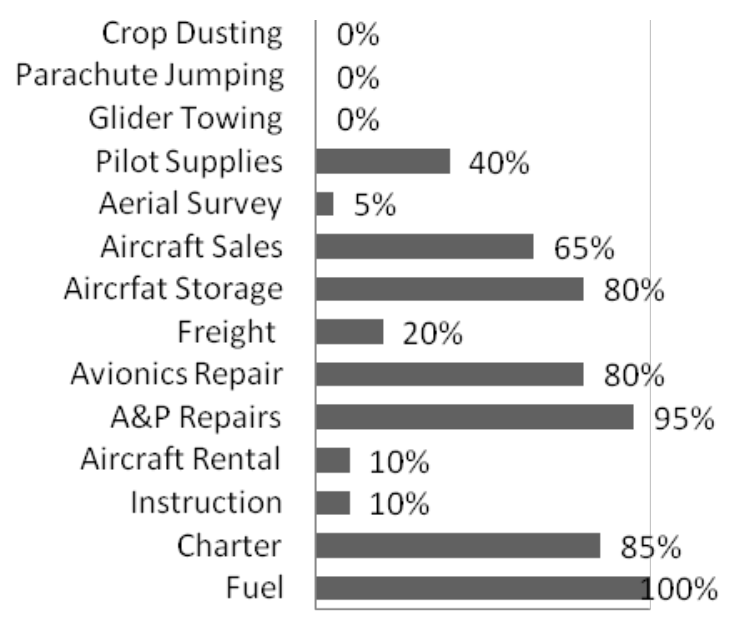

$0 \% 20 \% 40 \% 60 \% 80 \% 100 \%$

Figure 2. Services offered by the Top 20 responding FBOs

\section{CONCLUSIONS}

There has been little research or tabulation work done in the area of FBO employment. Figures on this subject are very difficult to find and are not contained in any United States Department of Labor statistical summary that the researchers could find. Nor were data contained in any available industry association publications. After two attempts at surveying general aviation FBOs for employment information, there is no doubt that this is an industry segment that either does not respond well to surveys, or is not used to being surveyed. This tendency is reflected in the relatively low response rate to the surveys. Using the NAICS data from the U.S. Census Bureau provides relevant employment numbers which show that as of 2001, nearly 8,000 establishments have over 175,000 employees engaged in FBO activity. This data provides a good source of overall employment numbers but lacks the detail of employment in specific job categories, services provided or regional influence within the field.

The WAD data shows very strong FBO employment in the South and Southeast regions of the country. Accordingly the states of Texas, Florida and Virginia accounted for nearly 64\% of all FBO employment nationwide. By combining our survey total with the WAD total we yield a net of 72,680 employees at FBOs in the United States of America with insight into type of employment found and the services offered. The three largest FBO employment categories were line service, mechanic and pilot/flight instructor. These data revealed that the most prevalent services provided by these employers were fuel services, aircraft storage, aircraft maintenance/avionics and charter/flight instruction. 
Table 5: Top 20 reporting companies and associated employment categories

\begin{tabular}{|c|c|c|c|c|c|c|c|c|c|}
\hline Company & City & State & Total & Mgmt. & $\begin{array}{c}\text { Flight } \\
\text { Instructor }\end{array}$ & Mechanics & Avionics & $\begin{array}{c}\text { Line } \\
\text { Service }\end{array}$ & $\begin{array}{c}\text { Customer } \\
\text { Service } \\
\end{array}$ \\
\hline Midcoast Aviation & Cahokia & IL & 1400 & 34 & 0 & 120 & 120 & 25 & 6 \\
\hline Duncan Aviation & Battle Creek & MI & 700 & 22 & 0 & 187 & 64 & 34 & 48 \\
\hline Stevens Aviation, Inc & Conestee & SC & 358 & 25 & 14 & 140 & 38 & 48 & 8 \\
\hline Million Air & Salt Lake City & UT & 320 & 25 & 36 & 30 & 0 & 57 & 6 \\
\hline Standard Aero & Springfield & IL & 250 & 8 & 0 & 75 & 30 & 4 & 50 \\
\hline Pentastar Aviation & Walerford & MI & 210 & 11 & 46 & 35 & 11 & 12 & 6 \\
\hline Hillsboro Aviation, Inc & Hillsboro & OR & 198 & 14 & 100 & 21 & 5 & 13 & 15 \\
\hline Epps Aviation & Atlanta & GA & 196 & 0 & 0 & 0 & 0 & 0 & 0 \\
\hline Western Aircraft, Inc & Boise & ID & 175 & 22 & 8 & 49 & 15 & 25 & 8 \\
\hline Atlantic Aero & Greensboro & NC & 169 & 5 & 0 & 57 & 7 & 14 & 3 \\
\hline Meridian & Teterboro & $\mathrm{NJ}$ & 156 & 11 & 58 & 13 & 1 & 46 & 9 \\
\hline Banyon Air Service & Ft. Lauderdale & FL & 156 & 19 & 0 & 27 & 14 & 36 & 9 \\
\hline Landmark Aviation & Sioux Falls & SD & 145 & 9 & 33 & 24 & 10 & 32 & 9 \\
\hline Spokane Airways Inc & Spokane & WA & 130 & 5 & 4 & 3 & 0 & 5 & 4 \\
\hline Northern Air & Grand Rapids & MI & 116 & 6 & 37 & 19 & 0 & 14 & 22 \\
\hline Jet Source, Inc. & Carlsbad & CA & 113 & 8 & 17 & 10 & 6 & 27 & 9 \\
\hline Landmark Aviation & Scottsdale & $\mathrm{AZ}$ & 106 & 4 & 11 & 25 & 3 & 45 & 18 \\
\hline The Flightstar Corp & Savoy & IL & 103 & 19 & 20 & 25 & 1 & 11 & 13 \\
\hline DB Aviation INC & Waukegan & IL & 100 & 20 & 30 & 15 & 0 & 20 & 5 \\
\hline Eagle Creek & Indianapolis & IN & 100 & 8 & 13 & 42 & 8 & 7 & 12 \\
\hline
\end{tabular}


APPENDIX A

FBO Employment Survey

Aviation Management and Flight

Applied Sciences \& Arts, Room 126

Southern Illinois University Carbondale

1365 Douglas Drive

Carbondale, Illinois 62901

Fax: $618-453-7286$

The purpose of this research is to update a study of aviation employment that was completed in 2003. One aspect of the research is to obtain an estimate of employment at Fixed-Base Operators in the USA. If you wish your FBO's employment numbers to remain confidential, please inform us so that we may protect that confidentiality. In any case, Southern Illinois University Carbondale will not publish the names of those contacted for this survey.

\section{FBO Information}

Name of FBO:

\section{Airport}

\section{Served:}

Contact

Person/Job Title E-mail

Address Phone

City, State, ZIP

Code

Do you wish your employment data to remain confidential?

Yes

No

Employment-Indicate the number of employees by the category of employment listed below:

\section{Total Number of Employees at this}

\section{FBO:}

How many employees are included in each category below?

(Insert number of employees in space provided)

$\square$ Management

Pilots/Flight Instructors

A \& P Mechanics

Avionics Technicians

Line Service

Customer Service

Other

Other

\section{Services Offered}

What services are offered at this FBO? (Check all that apply)

$$
\begin{array}{ll}
\square & \text { Fuel } \\
\square \quad \text { Charter } \\
\square \quad \text { Flight instruction } \\
\square \text { Aircraft rental } \\
\square \quad \text { Aircraft sales } \\
\square \quad \text { Aerial surveying } \\
\square \quad \text { Pilot supplies } \\
\square \quad \text { Glider towing }
\end{array}
$$

$\square$ Airframe/Powerplant repairs
$\square$ Air freight
$\square$ Avionics
$\square$ Aircraft storage
$\square$ Parachute jumping
$\square$ Crop dusting
$\square$ Other
$\square$ Other




\section{REFERENCES}

AC-U-KWIK: Global resource for aviation information (2008). Retrieved March 10, 2008 from http://www.acukwik.com/.

Aviation Week's World Aerospace Database. (Winter 2008). Section D13: FBO/Ground Handling/Fuel and Oil Worldwide, 934-960. McGraw Hill.

General Aviation Manufacturers Association (2008). What is GA? Retrieved March 31, 2008 from http://www.gama.aero/aboutGAMA/whatisGA.php.

Independent Fixed Base Operators Association. (2008). Our Members. Retrieved April 10, 2008, from http://www.ifboa.aero/fbolocator.cfm.

National Air Transportation Association. (2000). Aviation businesses and the services they provide.

NewMyer, D.A., Kaps, R. W., and Sharp, S. F. (1997, Spring). Aviation industry employment data estimates revisited. Journal of Aviation/Aerospace Education and Research. 7(3), 7-17

NewMyer, D.A., Korir, K. and Mehta, H. (2005, October). Employment at commercial service airports in the U.S.: Survey results”. Collegiate Aviation Review. 23(1), 45-65

NewMyer, D. A. and Owen, R. T. C. (2003, October). Aviation employment in the US: A review of data sources. Collegiate Aviation Review. 21(1), 46-59

NewMyer, D. A., Modjeski, C., Voges, J., and Bryant, J (2007, Spring). The importance of reliever airports in the U.S.. Collegiate Aviation Review. 25(1), 57-72

Rodwell, J. F. (2003). Essentials of Aviation Management: A Guide for Aviation Service Businesses (6 ${ }^{\text {th }}$ ed.). Dubuque, IA: Kendall Hunt Publishing.

United States Census Bureau. (2007). North American Industry Classification System. Retrieved November 1, 2008, from http://www.census.gov/cgi-bin/sssd/naics/naicsrch?chart=2007.

United States Census Bureau (2002) Retrieved May 1, 2009 from http://www.census.gov/cgibin/epcd/srchnaics02ind.

United States Department of Labor (2001). Report on the American Workforce. Retrieved March 15, 2008 from http://www.bls.gov/opub/rtaw/rtawhome.htm.

United States Department of Labor, Bureau of Labor Statistics (2007, May). National Industry-Specific Occupational Employment and Wage Estimates Retrieved December 4, 2008, from http://www.bls.gov/oes/current/naics3_488000.htm.

Wells, A. T., and Chadbourne, B. D., (2003). General Aviation Marketing and Management (2 ${ }^{\text {nd }}$ Edition), Krieger Publishing, Malabar, Florida. 


\section{Collegiate Aviation Review \\ SUBSCRIPTION ORDER}

The Collegiate Aviation Review is a refereed professional journal that publishes articles of interest in all areas of aviation research, aviation operations (both domestic and international), and the pedagogy of collegiate aviation. ISSN 1523-5955.

Please Print or Type

Name

Address

City, State, Zip

Country

Signature

Subscription Options

UAA Member subscription - \$40/year - 2 Issues

Non-member subscription - \$60/year - 2 Issues (U.S., add \$8 shipping \& handling; Non-U.S., add \$10)

Previous Issues available for Years 1985 - 2008 (Specify Year)

\$10 per issue (member), \$20 per issue (nonmember)

\section{Payment Options}

(Payable in U.S. funds only)

Check Enclosed (Payable to University Aviation Association)

Purchase Order Enclosed

Credit Card

VISA

MasterCard

AMEX

Card Number

Mail subscription order to: University Aviation Association 3410 Skyway Drive

Auburn, AL 36830

Phone: (334) 844-2434

Fax: (334) 844-2432 